Revue Française de Civilisation Britannique

\title{
Ideology, Institutions and Causes: the Committed Activist Life of a Durham Miner
}

La Vie engagée d'un mineur de Durham, Henry Bolton

\section{Lewis Mates}

\section{CpenEdition}

\section{Journals}

Electronic version

URL: http://journals.openedition.org/rfcb/1552

DOI: $10.4000 /$ rfcb.1552

ISSN: 2429-4373

\section{Publisher}

CRECIB - Centre de recherche et d'études en civilisation britannique

Electronic reference

Lewis Mates, «Ideology, Institutions and Causes: the Committed Activist Life of a Durham Miner », Revue Française de Civilisation Britannique [Online], XXII-3 | 2017, Online since 05 July 2017, connection on 23 April 2019. URL : http://journals.openedition.org/rfcb/1552 ; DOI : 10.4000/rfcb.1552

This text was automatically generated on 23 April 2019.

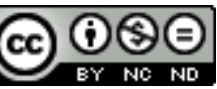

Revue française de civilisation britannique est mis à disposition selon les termes de la licence Creative Commons Attribution - Pas d'Utilisation Commerciale - Pas de Modification 4.0 International. 


\title{
Ideology, Institutions and Causes: the Committed Activist Life of a Durham Miner
}

\author{
La Vie engagée d'un mineur de Durham, Henry Bolton
}

Lewis Mates

\section{Introduction}

1 The rich and voluminous literature on British communism has been enhanced recently by the greater attention paid to support for its doctrines among mainstream Labour Party figures. ${ }^{1}$ Particularly pertinent is Kevin Morgan's study of A.A. Purcell's career path in the labour movement. ${ }^{2}$ With a militant, syndicalist background, Purcell became a leading trade unionist in the early 1920s; a Labour MP, he also helped found the Communist Party of Great Britain (CPGB). A central (though ultimately uninfluential) figure during the 1926 general strike, Purcell was edged out of influence in the aftermath of its defeat, part of a wider process of eliminating "non-party communism" from the later 1920s. ${ }^{3}$

2 Trade unionists operating at lower organisational levels of the mainstream labour movement, however, remain underexplored. Such activists could exert considerable influence for what were militant (and/or) communist causes by ensuring at least elements of the machinery of the mass movement were harnessed to promote them. Indeed, there remained a vast array of potential vehicles that influential local or regional labour movement activists could use to propagate their politics. These vehicles could be both from within the official machinery of the trade unions and Labour Party or unofficial institutions that sprang up in specific circumstances with often rather more focussed aims in mind. Using Morgan's work as a point of departure, this article explores the complexities of ideology and praxis through focussing on the life of Henry Bolton, a Durham miner and committed left activist, from the Edwardian period to the 1940s. ${ }^{4}$ 


\section{Methodism and (militant) socialism}

3 Henry Bolton was born in April 1874, in a Durham mining village just south of Chester-leStreet. The second sibling of a North Walian immigrant miner, after an elementary education, Bolton started work down the mine. While Chester-le-Street was a political storm-centre, there is no evidence that any of Bolton's family were especially politically active. It was religion, and specifically Methodism, that played the major role in Bolton's early cultural formation: in a sense, it was Bolton's first "cause". This was hardly surprising, as the various strands of Methodism were strong among the coalmining communities of the "Great Northern coalfield" (Durham and Northumberland) in this period. The Methodism of the Durham miners' late Victorian leaders underlay their economic and political Liberalism, emphasising miners' self-reliance, fostering coal owner paternalism, and informing the notion that master and men had shared interests in maintaining the wellbeing of the coal industry, achieved through conciliation and arbitration. $^{5}$

By the time Bolton signified his commitment to Wesleyan Methodism by signing the abstinence (from alcohol) pledge, in 1908, he was head of his own family and living in Chopwell, in the north-west Durham coalfield. ${ }^{6}$ With a modern colliery, Chopwell was a boom-town, attracting migrant coalmining families from across the region and further afield. The colliery's owners, the Consett Iron Company (CIC), were major industry players, turning large profits and paying generous dividends. Industrial relations were strained from the late 1890s, and Chopwell lodge (local union branch) was controlled by socialists of the ILP. The potential for the importation of radical ideas into this community in flux was high, and Bolton's conversion to socialism in this context was hardly aberrant, although by no means a given. ${ }^{7}$ Will Lawther, an active socialist from the age of fifteen whose own mining family had moved to the Chopwell from Northumberland in 1905, claimed to have converted both Bolton, and another ardent chapel-goer, Vipond Hardy, to socialism at a Chopwell ILP meeting. ${ }^{8}$ Though Lawther was fifteen years Bolton's junior, this event marked the birth of an important political alliance lasting to the late 1930 s.

In one crucial and fascinating sense, though, Bolton remained different from many of his new socialist comrades. In the wake of joining the ILP, Hardy moved away from Methodism, and began deploying his deep knowledge of the Bible to advocate a newfound militant atheism. Similarly, Lawther, though from a chapel attending family, also rejected religion early in life, as his socialist politics developed. Bolton, by contrast, retained his Christian faith. Again, though, this apparently rather idiosyncratic ideological standpoint was not entirely inexplicable. In the last years of the nineteenth century, Welsh minister Hugh Price Hughes developed and popularised Christian socialist ideas within the Wesleyan tradition, and Bolton certainly nurtured a friendship with him. 9

6 Other young ILP Durham miner militants were similarly active Methodists in this period: Jack Lawson, for example, whose conversion to Wesleyan Methodism immediately preceded his joining the ILP, in 1904, aged twenty-three. After summer 1911, Lawson became the leading figure in the Durham miners' minimum wage movement, galvanising its mass meetings with his aggressive class-based rhetoric. ${ }^{10}$ Bolton's own (private) attitude to industrial militancy was starkly evident in a letter to the militant Irish trade 
unionist Jim Larkin, in July 1914. Bolton praised Larkin's recent speech at Morpeth (Northumberland); "I think you rung the bell. [...] Your ridicule at the simple trust of the workers in obsolete methods and stage-coach leaders was excellently stated... [it was] a speech brim full of wise and daring statements. [...]"11 Yet, while Lawther was similarly enthusiastic about Larkin, Bolton did not appear to have been actively involved in Lawther's syndicalist (and then anarchist syndicalist) grouping in Chopwell.

\section{Working-class education and war resistance}

7 A Methodist desire for self-improvement, like that of many of his ILP-Methodist contemporaries, was evident in Bolton's passion for working-class (self) education. There were abundant opportunities for political education in Chopwell available through the libraries in both working men's clubs and the colliery institute, as well the Cooperative library, and the collections of individual activists. Bolton's first two causes, Methodism and socialism, thus combined to find practical expression in the third; education. This was manifest when Bolton established a Socialist Sunday School branch in 1913, which met at Lawther's non-sectarian "Communist (or Anarchist) Club", established in November 1913 and itself the product of Lawther's commitment to working-class education. ${ }^{12}$ The British Socialist Sunday School movement had begun in London in 1892, with Chopwell's branch forming part of a wider Tyneside network; all adopted the socialist "ten commandments" based upon mutual respect, tolerance and international fraternity.

8 Like many in the ILP, Bolton adopted an anti-war position in August 1914, and he began to use the Socialist Sunday School as a vehicle for fomenting anti-war resistance. After compulsory conscription was introduced, Bolton appeared at least two tribunals supporting local men applying for total exemption from war service on grounds of conscience. These included Will Lawther and his brothers Steve and Eddie. An apparently successful hearing in March 1916 saw all applicants granted exemption from combatant service. Eddie Lawther was not as fortunate six months later, however when Bolton's testimony that Eddie had been an active antimilitarist failed to help. The tribunal dubbed Lawther's objection simply "pernicious political propaganda" and he eventually served two years' hard labour in Wormwood Scrubs. ${ }^{13}$

9 The struggle against conscription also brought Bolton into new nationally-based organisations; the Union of Democratic Control and the No-conscription Fellowship. He was branch secretary of both in Chopwell and through them forged new alliances, most notably with Northumberland aristocrat C.P. Trevelyan, a former junior Liberal minister, radicalised by the war. Chopwell consequently became a significant coalfield centre of anti-war activity, attracting national speakers like the son of Lord Buxton who spoke there in 1916. But, with hardly a family in the village not directly affected by the war over two hundred from Chopwell were killed- the local environment was predominately hostile to the peace campaigners. ${ }^{14}$

10 The difficult context did, however, offer impetus to the working-class education movement, not least because it was easier and safer for socialists to propagandise within study classes than through more public means. In 1915, the North-east Labour College -an association of miners' lodges, trade union branches and socialist societies conducting study classes- was established..$^{15}$ By 1919 , Bolton was on its organising committee and that winter it ran sixteen classes in Durham and ten in Northumberland, chiefly on industrial 
history and economics. ${ }^{16}$ An incident that year encapsulated the confluence of Bolton's Methodism, his zest for working-class education and his politics, now further radicalised by the October 1917 Bolshevik revolution. In his capacity as Labour College organiser, Bolton met T.A. Jackson, a widely reputed working-class educator recruited to the Northeast College in autumn 1919. Jackson described Bolton as a "splendid type, he combined never-failing revolutionary ardour, with equally untiring practical work for a (Methodist) Brotherhood". ${ }^{17}$ The unintended result of a joke, Bolton brought Jackson to preach a sermon at his Brotherhood on "Isaiah the Bolshevik". The provocative title brought a packed house and a rapturous reception. The impact secured Jackson an increasingly inadequately sized venue for a lecture series on socialism in Chopwell.

Bolton's religion, politics, and passion for working-class education was evident too in his involvement in the Co-operative Society's adult education activities. In 1923 he won a prize for an essay on this very topic, rich with religious vocabulary and Biblical quotations, evidencing the refinement of Bolton's own (self-) education. ${ }^{18}$ The Cooperative Education Committee and North-east Labour College worked together on occasion, for example organising a talk in April 1920 by journalist W.T. Goode on "Bolshevik Russia as I saw it". The talk came at the conclusion of a Labour college class on industrial history conducted by Bolton, who afterwards received a token of appreciation of his efforts. ${ }^{19}$

\section{The ideal institution? Working through Blaydon Urban District Council}

12 Notwithstanding his work with Marxists through the Labour College, Bolton became an official of the newly-organised Blaydon constituency Labour Party (CLP). Crucially, the party offered Bolton a springboard for his public political career; he was duly elected a Labour representative for Chopwell ward of Blaydon Urban District Council (UDC) in April 1919..$^{20}$ The Urban District Councils in this period formed a significant part of local administration with extensive powers over house building, schools, sanitation, street improvements and road building, street lighting, recreation grounds, public conveniences, as well as administering the old Age Pensions Act. A seat on the council allowed Bolton to promote many causes.

Given the gross overcrowding in pit villages like Chopwell, working-class housing was Bolton's priority from the outset. He was soon condemning the scandalous (and prohibitive) cost of suitable building land, and trying to limit the building of new "luxury" buildings like picture halls or pubs, that took material, labour and land away from house-building. Instead of spending council money on "peace" celebrations, Bolton endorsed a proposal to build three "peace celebration" houses instead. Indeed, he made several other controversial interventions on the memorialisation of the war, attacking the hypocrisy of the men who were leading these efforts, yet failing to find ex-soldiers employment or to provide for the families of those killed or maimed in the war. Progress on house building was painfully slow and Bolton began to condemn the coalition government's apparent indifference, suggesting in August 1920 that the council should withdraw support for house building, thereby throwing full responsibility for the failure onto the government. Almost a year later, and with little change, Bolton's policy of noncooperation still could not muster majority council support. Even by January 1925, the 
council's nascent housebuilding programme had, according to Bolton, still not reduced overcrowding. ${ }^{21}$

The council proffered Bolton a platform to attack big business, and particularly the mine owners. He assailed them for refusing to build sufficient housing for their workforces; for buying up local farms and thereby imperilling the local milk supply and for neglecting to maintain Chopwell's streets. Bolton regularly sought, unsuccessfully, to find a means of delivering the benefits and rates rebates (of up to $30 \%$ ) enjoyed by the big house owners (like the coal companies) to single owner-occupiers and council renters. The rights, pay and conditions of the council's own workers were another cause, with Bolton arguing (unsuccessfully) in October 1919 for an extra one week's annual holiday on full pay for them all. He supported the council's own striking "cartmen" in November 1919 and was adamant that the council should always pay full trade union rates of pay, even to unemployed workers brought in by the government. Indeed, Bolton intervened on a vast raft of local issues, large and small; from arguing for the right of council tenants to keep poultry to advocating the municipalisation of local water. A council seat allowed Bolton to pronounce on national domestic issues too. For example, in December 1921 he got the council to endorse a call to prime minister Lloyd George to reduce the cost of foodstuffs. ${ }^{22}$

The council even allowed for interventions on international questions. In August 1920, Bolton moved to suspend council standing orders to allow for an emergency resolution that protested at the government's "bellicose attitude towards the Russian and Irish nations", opposed any British aid to the enemies of (Soviet) Russia and demanded the withdrawal of British troops from Ireland..$^{23}$ True, there was some opposition in the council; one councillor wanted nothing to do with it, as he was not elected for "political purposes". But the council nevertheless sent copies of its resolution to Lloyd George and the press. While Bolton had made the same case at the local labour mayday meeting that year, as an arm of the State, the council offered a more "respectable" platform. ${ }^{24}$ On the cause of preventing British intervention in Soviet Russia, Bolton was also active in the institution that sprang up specifically for this purpose. The organisational model of a national "Council of Action" constituted by the Labour Party and trade unions to argue the case and, if necessary, force the government's hand with industrial action, was replicated at local level. ${ }^{25}$ Thus, by late August 1920, Bolton was prominent in the Chopwell and district "Council of Action", moving its resolution "unreservedly to do anything within its power, including 'down tools' policy [sic.; a strike], to stop a wanton attack on Soviet Russia". ${ }^{26}$

16 The miners' cause, and work through the union, constituted the other major form of Bolton's activity in this period. A few months after the threat of intervention in Russia had been averted, Bolton was among the local miners' leaders dealing with the crisis brought about by government de-control of the mining industry and the owners' subsequent demands for wage reductions. On 20 March 1921, he moved the resolution at a Chopwell miners' meeting calling for a national conference of workers to resist wage reductions. ${ }^{27}$ Perhaps unsurprisingly, by May 1921 Bolton had come to the notice of the local police superintendent, who regarded him as a "leading light" of the Chopwell miners, though not "of a dangerous type as regards being the movers in militant acts". ${ }^{28}$

17 Ten months later, however, the superintendent was describing Bolton as "the only communist in office" in his area (though he did not "consider his influence to be strong enough to create any revolutionary activity"). ${ }^{29}$ Whether this meant that Bolton was understood to be a paid-up member of the CPGB or "communist" was simply a generic 
and pejorative term for any left-wing militant is uncertain. Bolton's activity to that point revealed a militant, active, anti-capitalist who opposed British intervention in Soviet Russia, but who seemed happy inside the Labour Party and whose name did not (unlike some of his Labour miner contemporaries) feature in communist publications. In this fluid period, such political identities were comparatively common, with Labour only beginning to proscribe communists from the mid-1920s. Certainly, Bolton's rhetoric sounded a militant note, but was not explicitly pro-communist. ${ }^{30}$ Indeed, when Labour formed a government in January 1924, Bolton was remarkably supportive. Presiding at a Mayday demo, he hailed the "real progress" achieved: "While they [Labour] were a minority government and could not legislate very much on revolutionary lines [sic.], yet they had done some things which the workers ought to be proud of [...]" ${ }^{{ }_{31}}$ In the council, too, Bolton was "fully satisfied" with the $£ 5,000$ of government support for housing that, he was certain, would not have been provided had Labour not been in power. ${ }^{32}$

Police surveillance records show Bolton remained active in Chopwell ILP branch, but was developing a closer working relationship with actual embryonic communist organisations, albeit some two years after the police first described him as a "communist". In March 1924, Bolton was one of twelve to attend a Young Communist League (YCL) meeting in the Chopwell, though the police were "unable to ascertain" what transpired. ${ }^{33}$ On 13 April 1924, Bolton was particularly busy, attending a suspected YCL meeting at about 2:30 p.m. and a Chopwell ILP meeting five hours later in the same venue. ${ }^{34}$ Then, in July, Chopwell lodge unveiled its newly-designed "red" banner, which carried (albeit, for various reasons, to the chagrin of some of Chopwell's inhabitants) a portrait of Marx. ${ }^{35}$ Bolton's specific role in the banner's design is uncertain but his status as a leading "red", certainly in the eyes of the police, was confirmed when he (and Will Lawther) became the subjects, in early 1925, of weekly police reports. ${ }^{36}$

\section{The "political" and "industrial" combine: Labour council majority, Lockout and general strike}

With Labour a minority in Blaydon UDC, Bolton's opportunities to advance his causes were limited. This changed with the April 1925 elections, when Labour won a dominant majority and Bolton was elected council chairperson. Aware that the press would be scrutinising the first Labour-run Blaydon council, Bolton was characteristically reminded of the entry of Jesus into Jerusalem. ${ }^{37}$ While his particular areas of interest continued, there was a cultural change, evident in the naming of streets of new council housing in Chopwell after, most controversially, Marx and Lenin in June 1925. The same month saw Chopwell's miners locked out, the result of their rejection of a reorganisation plan that included increased hours and reduced pay, itself an early response to the renewed national coal crisis..$^{38}$ Bolton had already shown clearly where he stood, launching a blistering attack on Peter Lee, a DMA fulltime official, in April 1925, in response to Lee's claim that miners would have to accept "'some new things which are not very palatable to us"' [...] The tears, the blood and the agony of the past are not going to be forgotten so lightly, no matter who gives the weighty advice, for other people to give away things which have been so dearly won". ${ }^{39}$ it protested at the "unnecessarily provocative", "large numbers" of police present in the 
village, which tended to provoke disorder ${ }^{40}$ Bolton supported his locked out fellow miners and their families by refusing to evict those in rent arrears to the council. He could also offer council jobs; for example, the locked-out miner Steve Lawther became a Blaydon UDC rent collector from July 1925, a post the council had only just established. ${ }^{41}$ Labour control of Blaydon UDC also allowed Bolton to frustrate government anti-strike plans. In December 1925 the council refused to comply with a government circular seeking local authority support for the organisation of supplies in the event of a nationwide coal stoppage..$^{42}$ Shortly before the general strike, Bolton sought to tighten his control on the council by "liberating" non-Labour councillors from committee work for the forthcoming year, though he dropped the plan after opposition from Labour as well as non-Labour councillors. ${ }^{43}$ Nevertheless, when the national mining lockout finally came on 1 May 1926, Blaydon UDC refused to appoint a "Coal officer" or to act on any of the other government emergency directives, despite repeated exhortations to do so. ${ }^{44}$

The TUC's general strike came into effect from midnight on 4 May. Naturally, Bolton was prominent in the discussion at a district mass meeting of trade unionists and others on the evening of Sunday 2 May at which Robin Page Arnot -a national CPGB leaderpresented a blueprint for action. Bolton's leadership of the council was essential to Page Arnot's plan..$^{45}$ Early next morning (Monday 3 May), Bolton went to Blaydon UDC offices and assumed control. He spoke to all the staff, instructing those he did not trust to take their holidays immediately. He then turned the remaining staff, offices and machinery "into an organ of the general strike". ${ }^{46}$ This was vital to the propaganda effort as the council's duplicator was required to produce the strike broadsheet Northern Light. ${ }^{47}$

The first issue of Northern Light appeared the next morning, Tuesday 4 May. On Bolton's authority, the duplicator was transferred in a maternity van under the cover of night to the first of the various hide-outs; appropriately enough an unfinished Chopwell council house. The duplicator's hiding place changed regularly, to prevent the police from seizing it. The local lockout "Council of Action" a (note the nomenclature taken from the "Hands off Russia" movement) also benefitted from the council in that its headquarters was the council's Sanitary Inspector's office, and next door to Chopwell police station! ${ }^{48}$ Eyewitness accounts suggest a highly active and very well coordinated body, organising round-the-clock picketing, producing and distributing Northern Light, and running the soup kitchen. ${ }^{49}$ Several days into the general strike, Bolton was upbeat: "We have the people behind us. We have paralysed the traffic [...] Let Baldwin [the prime minister] resign, and his other tools Capitalism and greed. ${ }^{50}$

23 However, Bolton's crucial organising role lasted only five days into the general strike. On Sunday 9 May, he was in a car with Will Lawther and the driver, Jim Frost, returning to Chopwell from Blaydon where they had investigated (unfounded) rumours that the police had baton-charged a crowd. Stopping on the way home at a pub, the three came into a confrontation with the police, resulting in Bolton and Lawther's arrests. The evidence given by the police at the trial, and Lawther's later accounts, suggested that it was only when the Police Inspector went outside to talk to Bolton (on Lawther's suggestion) that the arrests became unavoidable (as a teetotaller, Bolton had stayed in the car). Interestingly, Bolton's threats to prevent the police from delivering a lorry load of foodstuffs Lawther attributed to his being an "excitable fellow - a Methodist", as if the two were intimately related! ${ }^{51}$

At Gateshead Court on Thursday 13 May, both men stood charged under the Emergency Powers Act (EPA) with interfering with food distribution and police intimidation. Bolton 
was in a particularly curious situation as his chairmanship of the council meant that he was a Justice of the Peace who could preside at the very court he appeared before. ${ }^{52}$ The trial proceedings offer a window onto Bolton's politics, as the prosecution claimed both men were "prominently connected with the communist movement which, unfortunately, was very rife in the neighbourhood of Chopwell" ${ }^{53}$ Bolton denied being in the CPGB, and claimed that "I have always urged the men not to use force. I have walked round "til half past two in the morning urging the pickets to work peacefully and refrain from violence". ${ }^{54} \mathrm{He}$ also claimed not to know if Northern Light was printed on council paper, though he agreed that it was similar to paper he got his council minutes on! After a six-hour trial, the two accused were found guilty. Both refused the $£ 50$ fine and so went to gaol for two months. Outside the court, there were violent scenes as the police attacked a supportive crowd..$^{55}$ Coincidentally, the TUC called off the general strike the same day.

So effective were Bolton's arrangements for the regular relocation of the duplicator that even by 20 May the police had still not been able to seize it. ${ }^{56}$ Bolton played a vital role in making the north-east one of the best organised regions during the general strike. Thanks to him Blaydon UDC provided the one known example of a council providing direct assistance to the strike organisers in the entire region. ${ }^{57}$ Page Arnot's account also mentioned Bolton, the "outstanding figure" at Blaydon, which "as far as Durham County was concerned remained the storm centre throughout"..$^{58}$ His arrest made Bolton, momentarily, a national figure. (The trial had been the subject of a question in Parliament). ${ }^{59}$ According to Page Arnot, Bolton and Lawther's were the "most sensational" arrests of the more than two-hundred Durham and Northumberland miners detained under the EPA. ${ }^{60}$

These events meant that Bolton was helping to build Chopwell's reputation as a communist stronghold; a "Little Moscow". To that point the epithet was unfounded, at least in terms of paid-up CPGB members in the village: even Bolton himself was not yet one of those. ${ }^{61} \mathrm{~A}$ week after the Bolton's imprisonment, forty-seven arrested during the general strike (mostly from the Chopwell district) appeared in court. The prosecutor dubbed the local "Council of Action" a "terrifying and despicable organisation". Bolton's placing of council resources at its disposal was apparently "known now as "The Blaydon Scandal". ${ }^{62}$ Presiding, Sir Alfred Palmer (the Jarrow shipping magnate) said to the accused; "why you don't go to Russia I don't know, nobody wants you here". ${ }^{63}$

At a hero's welcome home meeting the day after his release on Saturday 27 June, Bolton remarked characteristically that he told the chaplain in gaol that 'Chopwell is a city set on a hill that cannot be hid -(laughter)- and the only thing that differentiates it from other towns is that it is a little bit higher in intelligence and in outlook than most of the other towns'.$^{64} \mathrm{He}$ then held up a red flag, saying it was "symbolical of a movement" that would destroy capitalism and build in its place a new Jerusalem. ${ }^{65}$ Now released, Bolton re-engaged in the miners" struggle, though he managed to stay out of the courts. Chopwell itself remained quiet, as it was solidly out until early October 1926. In early December, the Chopwell miners voted to return to work, on worse terms than those rejected in March 1926. ${ }^{66}$ 


\section{Full communism realised? Into the CPGB (and out again)} when Bolton was among the British delegates (led by Will Lawther, chair of the British "Friends of Soviet Russia" section) to the Soviet Union. ${ }^{72}$ So impressed was Bolton that he formally joined the CPGB for the first time on returning home. The first reference to his new party affiliation came in July 1928, when Workers' Life described Bolton as "still a Labour councillor despite being a communist", whose dole money was being paid to him by Chopwell lodge. ${ }^{73}$ This was in defiance of the DMA executive, who wanted the payments stopped precisely because of Bolton's new explicit communist loyalties.

Unsurprisingly, given his central role in the miners' effort, Bolton was among those victimised by the coal owners, but he did not -unlike many blacklisted miners- emigrate. ${ }^{67}$ Initially unemployed, Bolton's staying put paid off when he was elected Chopwell colliery checkweighman in 1928. Chosen and paid for by the miners, the checkweighman's vital task was to ensure that the tubs of coal -on which the piecework wages of the majority of underground workers were based- were accurately weighed. This represented a considerable achievement and was testament to how high Bolton's local profile had risen during 1926. He was now in an even more influential position within the highly organised miner's union. ${ }^{68}$

Interestingly, Bolton's politics also altered. His early sympathy for Bolshevism and the Russian revolution and low-key activity with the YCL was now increasingly characterised by a closer overt working relationship with the CPGB as, in summer 1927, his name began appearing in communist publications for the first time. In May 1927, the CPGB's weekly paper Worker's Life recorded that Bolton and Will Lawther sent letters of greeting to a YCL conference in Newcastle that elected a representative for a delegation to the Soviet Union. ${ }^{69}$ Only these two were mentioned as explicitly Labour supporters of the event. The same edition reported that Bolton, described as a local ILP left-winger, spoke at a YCL/ CPGB demonstration of two-hundred children with red rosettes and banners on the occasion of "Empire Day", a State-sponsored event that had seen Bolton embroiled in controversy in the past. ${ }^{70}$ Within three months, Bolton (and several Lawthers) were prominently involved on the Labour side of communist initiatives to form a "united front" of the left in Chopwell. A Chopwell CPGB branch public meeting on the mining situation on 28 August resulted in the formation of a "united front committee", involving communist, Co-operative guild, and Labour Party sections. Later that same day, at the "best attended meeting in Chopwell", Bolton moved the new committee's motion. ${ }^{11}$ Direct emotional ties to the Soviet experiment were strengthened in November 1927 The timing was unfortunate: Bolton's "united front" approach to left politics, so germane in the immediate aftermath of the miners' lockout, and significant in understanding his decision to join the CPGB, was becoming rapidly outdated. The international communist movement was in transition to its aggressively sectarian "third period" of "class against class", when it began identifying the rest of the left as "social fascists" that should be ruthlessly exposed rather than cooperated with. By mid-February 1929, Bolton had been expelled from the CPGB over a Chopwell mining dispute. The local management had given its workforce a week's notice to sign back individually on reduced piecework rates. The CPGB had taken up the men's cause, but it also criticised DMA officials openly for negotiating an apparently unsatisfactory settlement. Bolton disassociated himself 
publicly from the communist position and was consequently expelled for "indiscipline and political unreliability. ${ }^{74}$ His time inside the CPGB did not appear to damage Bolton's local political career or standing. Of his expulsion, the North Mail commented that Bolton remained "one of the best-known men in the district", and "still an ardent Socialist" presiding over a "Socialist" council. ${ }^{75}$

This short stint in the CPGB and the manner of Bolton's departure reveal why he did not join earlier. Inside the Labour Party and trade unions there were no apparent attempts to discipline him; he could thus act to promote his politics with impunity and a position of considerable local, district and, increasingly, regional importance. Electorally, too, the communist label was a likely hindrance, even to a figure with the local following of Henry Bolton. Even the supposed "Little Moscow" of Chopwell did not elect communist councillors in this period; the Labour label was a prerequisite for electoral success. More generally, the "third period's" sectarianism was inimical to mass membership in villages like Chopwell; its CPGB branch had a mere four members by $1933 .{ }^{76}$ Bolton could be far more effective, and politically freer, operating inside the Labour Party and unions.

\section{Peace councils, United and Popular Fronts}

The renewed salience of international events in the early 1930s saw Bolton become involved in a new institution as the emphasis of his activity shifted towards foreign affairs; the League of Nations Union (LNU). This was an anti-war organisation promoting the League of Nations to prevent future conflicts between nations escalating into war, whose local branch memberships could differ considerably from its rather liberal national leadership..$^{77}$ By 1934 Bolton was a leader in Chopwell's LNU branch, though cooperation with communists who were keen -after the Nazi success in Germany was attributed to a fatally divided left- to become rehabilitated among the wider left, was initially fraught. In July 1934 Bolton led the miners' contingent in a diverse, Chopwell LNU-organised procession and mass rally in the village. The local communist-run (reconstituted) "united front committee" was informed that its involvement was not desired, as the procession -which included schoolchildren, the Women's Institute, British Legion and church representatives- was "non-political". Subsequent attempts to join in regardless precipitated the arrest of five local communists. ${ }^{78}$

By 1936, Bolton's activism on international affairs and peace was also manifest in his toplevel involvement in the Tyneside Joint Peace Council (TJPC), one of very many such organisations formed across Britain in the wake of the "Hands off Abyssinia" campaign (against Mussolini's intervention there) in autumn 1935. Bolton chaired the TJPC, composed of multifarious organisations and individuals from across the region that offered a new vehicle for cooperation on the left. It afforded Bolton a chance to experience transnational activism as, in late June 1936, he was elected among five TJPC delegates to the World Peace congress in Brussels, scheduled for that September. ${ }^{79}$

Through the TJPC, Bolton became integral to the regional labour movement's response to the Nationalist uprising in Spain against the Republican government in July 1936. At a TJPC meeting in Newcastle in early August 1936 Bolton moved the motion demanding that the government take a "sharp line" against fascism and exhorting British labour to campaign for the Republic and a "People's front". ${ }^{80}$ The TJPC's demand that the government refuse export licences to Spanish Fascists but supply arms to the Republic was both clear and radical (considering the national labour movement's initial acceptance 
of Non-Intervention). It was also the first public statement on the conflict from the left appearing in the regional press. ${ }^{81}$ The TJPC organised meetings on Spain and other international issues throughout the late 1930s, its events in South Shields lending credibility to its Tyneside pretensions.

As TJPC chairperson, Bolton criticised not only the Conservative dominated National government's foreign policy, but the response of the "weak-kneed Labour Party" as well. ${ }^{82}$ (Labour's northern MPs he deemed "far too tame and respectable in the House of Commons", on domestic policy as well; in this case when arguing for more help for unemployment stricken Jarrow. $)^{83}$ Bolton's outspoken public stance drew considerable criticism; over whether, for example, the TJPC was "nothing more than a disguise for the machinations of extreme socialists". ${ }^{84}$ In spite of some local Catholic labour movement disquiet, the desperate international situation, and particularly Spain, rekindled Bolton's demands for a united front of the left. Practically, as TJPC chair, he was coming into close working contact with communists. ${ }^{85}$

Other institutional positions Bolton used to fight for the same causes. As Blaydon CLP secretary, he called for a united front including communists to combat fascism and save Spain in the party's 1936 annual report. Arguing for the need to "do away with class society", and that the "inevitability of gradualness" (famously associated with the Webbs who continued to exert influence inside the party) did not work, meant Bolton remained firmly on the party's left. ${ }^{86}$ Integral to Blaydon CLP's anti-war and anti-fascist exhibition, opened in August 1936, Bolton was quick to praise the lead Will Lawther (a DMA fulltime official since 1934) and his colleagues "have given us miners" over Spain. ${ }^{87}$

The council chairmanship offered another avenue, with Bolton issuing a long statement on the Spanish situation to the council, reported in the local press in mid-August $1936 .{ }^{88}$ Council influence also facilitated practical united front activity. In late August 1936, Blaydon UDC received a deputation from the communist-inspired National Unemployed Worker's Movement (NUWM) ${ }^{89}$ It was led by Wilf Jobling, whose political formation had begun in Bolton's Socialist Sunday School (from 1915, aged only six) and who had subsequently worked with Bolton during the 1926 lockout (when only just out of school, having won a scholarship to secondary school).${ }^{90}$ Bolton reassured the deputation that its (several) proposals against the government's punitive Unemployment Assistance Boards would be "favourably considered". ${ }^{11}$ When the locality's NUWM national Hunger March contingent set off in October 1936, Bolton was among the well-wishers; he received them at the council buildings on their return from London in mid-November. ${ }^{92}$

Several north-east Hunger Marchers then went to fight in the International Brigade in Spain from late 1936, among them Wilf Jobling. After Jobling died fighting at Jarama, in February 1937, Bolton paid a moving tribute at a council session..${ }^{93}$ Shortly after this, however, Bolton stood down from Blaydon UDC, after serving eighteen years, and was elected instead to Durham County Council. While this allowed him to pursue his passion for education further, his personal influence inside the County Council was necessarily diminished in comparison with that in Blaydon UDC. ${ }^{94}$ Nevertheless, his speaking out was still reported; for example, he denounced the expulsions of two former Labour Party activists and Jarrow March leaders, an episode that he thought brought "disgrace" on Labour. ${ }^{95}$

An eagerness to keep good activists inside an open and tolerant Labour Party, and to work with communists outside of it, broadened in 1938 to support for a popular front of all anti-fascists, including Liberals (and in some cases even "progressive" Conservatives). 
${ }^{96}$ As with many other leftists, the Spanish Republic's deteriorating situation was the catalyst, evident in the numerous references to Spain in Bolton's mayday 1938 speech and particularly to a recent unofficial national emergency conference on the issue that he had attended as Blaydon CLP delegate. Bolton quoted approvingly Liberal MP Wilfred Roberts" willingness to work with anyone who wanted to help Spain; he also mentioned the role of his political ally C.P. Trevelyan (now a retired Labour left-winger), whose call for a Popular Front had received a "great reception". ${ }^{97}$ At a second mayday demonstration that year, Bolton shared the platform with a local communist officer of the International Brigade..$^{98}$

41 With the growing clamour for a Popular Front, Bolton became active in what were initially rather ad hoc propaganda events. Drawing influence from his leading position in his CLP and union, as well as his regional role with the TJPC, Bolton was an obvious leadership figure for regional Popular Front initiatives. Thus, in May 1938, he presided at a United Peace Alliance conference in Gateshead, criticising movement leaders who wanted the British government to cooperate with other democracies against Fascism, but who were not also prepared to join with other democratic organisations against the Chamberlain government. Bolton's confidence that "the rank-and-file of Labour would support a United Peace Alliance" seemed justified in that over three-hundred delegates were in attendance representing various Labour and other "progressive" organisations. ${ }^{99}$ In fact, the May 1938 conference proved a one-off, failing to galvanise the regional labour movement. ${ }^{100}$

Apparently undeterred, in February 1939 Bolton was quick to add his name to that of C.P. Trevelyan as the first signatories of Labour leader Stafford Cripps' petition in a more formalised effort to win the Labour Party to the Popular Front. Bolton was on Cripps' Newcastle meeting platform, which drew a crowd of 3,200; Will Lawther's signature followed. ${ }^{101}$ Opposition to Cripps' campaign among national Labour leaders was, however, evident at regional level, though Bolton stood firm at a regional Labour Parties meeting convened to discuss it, attacking the national Labour leadership for "rejecting workingclass unity" while simultaneously collaborating with the Conservative-dominated government. ${ }^{102}$ Yet, while Cripps' campaign was floundering -support melted away as Labour's national leadership began expelling members- the Tyneside foodship campaign was in full swing. Launched in December 1938 by Bolton's TJPC, it quickly mushroomed, eventually raising around $£ 4,500$ in $3 \frac{1}{2}$ months of intensive region-wide campaigning and thereby becoming the single largest of the region's humanitarian Spanish aid campaigns. Though it galvanised activists of most political parties and none in effective cooperation, the Tyneside foodship had no tangible bearing on the "political" Popular Front campaign, not least as its leading activists tended to emphasise the campaign's humanitarian neutrality. ${ }^{103}$ Bolton was to realise that the experience of Chopwell and district was not replicable in a wider north-east political culture that remained more hostile to cooperation with those both to the "left" and right of Labour.

\section{A true "fellow traveller"? The Finland grant dispute}

The later 1930s saw Bolton's politics chime with those of a grouping of left-wingers from Chopwell that included Will Lawther and his brothers, Steve and Andy. They were all Labour Party members, but also overtly sympathetic towards the CPGB and its off-shoots (like the NUWM) without possessing a party card. Indeed, aside from this last feature, 
they all spoke and behaved pretty much as British communists of the time did, prioritising the same campaigns and issues. The Hitler-Stalin Non-aggression Pact on 22 August 1939 changed this dramatically, at least for Will Lawther, who turned strongly against the communists' "indescribable cynicism". ${ }^{104}$ This was merely compounded when the CPGB declared (and after some confusion) its neutrality in what it dubbed an 'imperialist' war that broke out in September 1939.

The Soviet Union's invasion of Finland in November 1939 revealed the depth of Bolton's adherence to the CPGB "line". In February 1940, the DMA executive proposed to grant $£ 1,000$ to a fund supporting the Finnish government against the Soviet Union. ${ }^{105}$ Bolton's name appeared among twenty-five signatories to a leaflet attacking the proposal and depicting the conflict as (Finnish) capitalism versus (Soviet) socialism. ${ }^{106}$ Their efforts to convince Durham lodges were in vain, as they endorsed the grant by $787-47$ votes. Then, on 19 March 1940, the DMA council (in theory the union's governing body) endorsed an executive decision that all the leaflet's signatories be fined and sign an apology. Bolton was one of only two to refuse, informing the executive that he would apologise "when Mr. Will Lawther did so in respect of similar crimes he had committed". ${ }^{107}$ On 22 April 1940, both men were expelled from the union. Two years later their appeal went to Durham Chancery court.

The plaintiffs argued that the leaflet was merely "honest political criticism of a line of action", and "did not constitute a vicious or libellous attack upon anyone". ${ }^{108}$ Bolton argued that events had vindicated the leaflet's claims. The defence suggested that the leaflet was almost identical to communist propaganda, and that the signatories did not write it. Yet, several highly critical references to Will Lawther's role in court suggested that Bolton had had a significant input into the leaflet's text. He admitted having been a CPGB member for "a few months" in 1928, offering an account of his leaving the party that tallied with the contemporary evidence (above). ${ }^{109}$ While some of the leaflet's signatories were CPGB members, fellow plaintiff John Jeffrey claimed never to have been a communist, denied receiving communist financial help towards the court case, and did not regard the leaflet as a communist document. ${ }^{110}$ Jeffrey was seventy-six by this time, Bolton sixty-eight; like Bolton, Jeffrey was a checkweighman, and long-standing activist, having been prominent in the socialist rank-and-file movements before the Great War. Neither had much to lose. ${ }^{111}$ After a three-day hearing, the Chancellor ruled the DMA executive's action null and void as it had refused the plaintiffs a fair hearing. ${ }^{112}$

The ruling vindicated Bolton (and Jeffrey) but, by April 1942, the geo-political landscape had altered dramatically. The Nazi offensive on the Soviet Union in summer 1941 saw the CPGB line change to whole-hearted support for the war effort. Jeffrey, who regarded the war as "imperialist" in February 1940, claimed in court that it "ceased to be an imperialist war after the manoeuvring to get us into a war with Russia ceased". ${ }^{113}$ This was likely Bolton's position too. Will Lawther, now MFGB president was, by July 1942, calling for a second front to be opened up to relieve the pressure on their Soviet allies in the east. His urgent calls to further boost coal production and increasingly vitriolic attacks on shirkers and strikers among the miners now chimed perfectly with those of British communists, and their Labour sympathisers like Bolton. ${ }^{114}$ 


\section{Conclusion}

47 Henry Bolton continued as a Durham County Councillor until April 1949, when he stood down aged seventy-four. ${ }^{115}$ The final years of his public life were lower profile, his last major battle fought in 1942 inside one of the first institutions in which he had sought to act; the miners' union, and appropriately enough, over how it should (not) spend its funds intervening in the wider world. In the post-war period, as Will Lawther became an increasingly virulent anti-communist, Steve and Andy Lawther remained sympathetic to the Soviet Union and British communists and corrosively critical of their eldest brother's politics. While Bolton's politics was similar to these younger Lawthers, there was one stark difference: he remained a committed, practising Methodist throughout his life. His politics were perhaps best summarised by his remarks from a public platform in 1924: "if ever there had been a religious movement in the world, then the Labour and socialist movement was a religious movement, because they stood for absolutely the highest ideals in human life". ${ }^{116} \mathrm{He}$ contrasted, too, with his pre-Great war radical Methodist contemporary Jack Lawson, who adopted much more moderate politics after 1918, on being elected an MP and becoming an Attlee government minister. ${ }^{117}$ The strains that communist atheism might have placed on Bolton's evident commitment to communist causes were never apparent in his political interventions; quite the opposite, in fact. If Bolton's socialism was unusual it was not entirely aberrant, nor even particularly oldfashioned. Indeed, his politics in some respects anticipated that of Tony Benn's radical phase from the later 1970s. Benn claimed his own politics owed "much more to the teachings of Jesus -without the mysteries within which they are presented- than to the writings of Marx whose analysis seems to lack an understanding of the deeper needs of humanity". ${ }^{118}$ Bolton, too, had taken political inspiration from the Bible, in developing a socialism that, aside for atheism, had much in common in rhetoric and praxis with that of British Marxists.

Nevertheless, Bolton remains particularly interesting and, ideologically speaking, comparatively unusual. But he was also significant, as he played a leading role in advancing his complex and diverse political agenda in both established (often long-term and national-based) institutions like the Labour Party and the miners' union, as well as in more local and regional based ones, like the TJPC. The often ad hoc, issue-focussed institutions tended to be more cross-class and politically diverse (the Union of Democratic Control, No-Conscription Fellowship, LNU, TJPC) and focussed on international questions (with the exception of the "Hands off Russia" "councils of action".) Bolton's political priorities varied depending on context, institution and circumstances; from advancing working-class education, to agitating against the war and then its legacies, to promoting working-class housing in the council, to the miners' struggle for a decent living, to issues of peace and anti-fascism in the 1930s. It was remarkable, too, that he was able to use an organ of the local State, Blaydon UDC, to promote effectively many aspects of his radical agenda. But the narrowness and discipline demanded by the CPGB was simply inimical to his much more politically open praxis; the machinery of the mainstream labour movement provided him with, for the most part, perfectly suitable vehicles.

While the task of piecing Bolton's praxis together over time is necessarily, given the sources available, patchy, there remains a clear enough picture of a deeply principled 
miner activist who valued working-class self-education and improvement, who hated capitalism and the abuses that accompanied it, and who, like many on the Labour left in his period, genuinely regarded the Soviet Union as lighting the way to a better, socialist future. While there seemed little room in the movement for national left leaders like A.A. Purcell after the later 1920s, important district and regional activists like Bolton could still prosper merely a rung or two down the hierarchy, apparently too powerful to be removed or disciplined from within the regional movement and either not regarded as significant enough, or, given a lack of personal ambition, simply not amendable to discipline from above. Bolton's death came in the same year as Stalin's, so he did not live to hear the Khrushchev revelations nor react to the Soviet invasion of Hungary in 1956, that saw so many British communists renounce their "god that failed". ${ }^{119}$ These traumatic events seemed not to impact on the politics of the younger pro-communist Lawther brothers. It is tempting to speculate whether Bolton's independence of thought, his zest for truth and knowledge, and his generous interpretation of what constituted the underdog would have seen him become more critical of the lead coming out of the Soviet Union.

Lewis Mates is a tutor in Politics at Durham University. He has published widely on twentieth-century British political history including The Spanish Civil War and the British Left (London: I.B. Tauris, 2007). His most recent monograph, The Great Labour Unrest: Rank-and-file movements and political change in the Durham coalfield, was published by Manchester University Press in 2016. He is currently writing a book on Edwardian anarchism and working on a research project on the teaching of local mining history in post-industrial communities.

\section{BIBLIOGRAPHY}

Barron, H., The 1926 Miners' Lockout. Meanings of Community in the Durham Coalfield (Oxford: Oxford University Press, 2009)

Challinor, R., "Jimmy Stewart and his Revolting Children", Bulletin of the north-east Group for the Study of Labour History, 17 (1983) pp.8-12

Cope, D. Bibliography of the Communist Party of Great Britain (Lawrence and Wishart, 2016)

Crossman, R. (ed.), The God That Failed. Six Studies of Communism (Hamish Hamilton, 1950)

Jackson, T.A., Solo Trumpet: some memories of socialist agitation and propaganda (Lawrence and Wishart, 1953)

MacIntyre, S., "Red Strongholds Between the Wars”, Marxism Today (March, 1979), pp.85.

Mason, A., "The Miners' unions of Northumberland and Durham, with special reference to the General Strike of 1926" (Ph.D. thesis, Hull University, 1967)

Mates, L. “Syndicalism and the 'transnational turn”', Capital \& Class 40:2 (2016), pp. 344-354

Mates, L.H., The Great Labour Unrest; rank-and-file movements and political change in the Durham coalfield to 1914 (Manchester: Manchester University Press, 2016) 
Mates, L.H., "The Limits and Potential of Syndicalist Influence in the Durham Coalfield before the Great War", Labor History, 54:1 (2013), pp.46-47

Mates, L.H., "Radical Cultures and Local Identities: the North-east Labour Movement's Response to the Spanish Civil War", in K. Cowman and I. Packer (eds), Radical Cultures and Local Identities (Newcastle: Cambridge Scholars, 2010), pp.213-231

Mates, L.H., The Spanish Civil War and the British Left: Political Activism and the Popular Front (I.B. Tauris, 2007)

Mates, L.H., "Durham and South Wales Miners and the Spanish Civil War", Twentieth Century British History, 17:3 (2006), pp.383-385

Mates, L.H., "The North-East and the Campaigns for a Popular Front, 1938-9", Northern History, 43:2 (2006), pp.273-301

Mates, L.H., "A 'Most Fruitful Period'? The North East District Communist Party and the Popular Front Period, 1935-9", North-East History, 36 (2004), pp.54-98

Mates, L.H., "Britain's De Facto Popular Front? The Case of the Tyneside Foodship Campaign, 1938-1939”, Labour History Review, 69:1 (2004), pp.323-345

Morgan, K. Bolshevism, syndicalism and the General Strike: The lost internationalist world of A.A. Purcell (Lawrence and Wishart, 2013)

Morris, M., The General Strike (Penguin, 1976)

Mullin, C., (ed.), Arguments for democracy (Harmondsworth: Penguin)

Page Arnot, R., et. al., “The General Strike, 1926”, Our History, Issue 22 (1961), p.27

Short, G., "The General Strike and Class Struggles in the North-East: 1925-28”, Marxism Today, Volume 14 (October, 1970), pp.306-315

Turnbull, L., Chopwell's Story (Gateshead: Gateshead council, 1978)

Watson, D., No Justice without a Struggle (Merlin Press, 2014)

\section{NOTES}

1. D. Cope, Bibliography of the Communist Party of Great Britain (Lawrence and Wishart, 2016).

2. K. Morgan, Bolshevism, syndicalism and the General Strike: The lost internationalist world of A.A. Purcell (Lawrence and Wishart, 2013).

3. Instructive too is the burgeoning work on syndicalist and anarchist activism under the rubric of the "transnational turn", with its emphasis on actor networks. See L. H. Mates, "Syndicalism and the 'transnational turn"', Capital \& Class 40:2 (2016), pp. 344-354.

4. I would like to acknowledge the generous help of Jack Fletcher (Bolton's grandson), Emmet O'Connor, Kevin Davies and Don Watson, and the anonymous reviewers.

5. L. H. Mates, Great Labour Unrest, pp. 49-52.

6. "Independent Order of Rechabites, Salford Unity, Friendly Society. Declaration of Candidate", 4 September 1908 (in possession of Jack Fletcher); Blaydon Courier, 13 March 1953; Turnbull, L., Chopwell's Story (Gateshead: Gateshead council, 1978), n.p.n.

7. L. Turnbull, Chopwell's Story, n.p.n.; Mates, Great Labour Unrest, pp.60-61, 63-64.

8. Newcastle Journal, 15 March 1955.

9. Blaydon Courier, 13 March 1953; Newcastle Journal, 8 March 1955; Turnbull, Chopwell's Story, n.p.n. 
10. L. H. Mates, Great Labour Unrest, pp.147-286.

11. National Library, Dublin, William O’Brien mss, MS 15679 (1), Henry Bolton letter to Jim Larkin, 19 July 1914.

12. L. H. Mates, "The Limits and Potential of Syndicalist Influence in the Durham Coalfield before the Great War", Labor History, 54:1 (2013), pp.46-47.

13. Blaydon Courier, 30 September 1916; Challinor, R., "Jimmy Stewart and his Revolting Children", Bulletin of the north-east Group for the Study of Labour History, 17 (1983) pp.8-12.

14. Blaydon Courier, 11 March 1916; 30 September 1916; "Henry Bolton" in "The Pearce Register of British WW1 Conscientious Objectors" available online at https://livesofthefirstworldwar.org/ lifestory/7657095 (Accessed: 31 May 2016); L. Turnbull, Chopwell's Story, n.p.n.

15. Newcastle Journal, 17 March 1955; Jackson, T.A., Solo Trumpet: some memories of socialist agitation and propaganda (Lawrence and Wishart, 1953), pp.143-44.

16. Blaydon Courier, 1 May 1920.

17. T. A. Jackson, Solo Trumpet, p.156.

18. H. Bolton, The Place of the Co-operative Movement in the Sphere of Adult Education (Pelawon-Tyne: Co-operative Wholesale Society, 1923).

19. Blaydon Courier, 24 April 1920.

20. Ibid., 12 April 1919; 3 May 1919.

21. Ibid., 19 May 1919; 14 June 1919; 14 August 1920; 12 March 1921; 2 April 1921; 18 March 1922; 21 July 1923; 25 August 1923; 24 January 1925.

22. Ibid., 18 October 1919; 15 November 1919; 14 May 1921; 16 July 1921; 3 December 1921; 11 February 1922; 20 December 1922; 20 January 1923; 14 March 1923; 21 April 1923; 23 June 1923; 27 October 1923; 14 November 1923; 23 February 1924; 22 March 1924; 22 November 1924; 20 December 1924.

23. Ibid., 14 August 1920.

24. Ibid., 8 May 1920.

25. Ibid., 14, 21 August 1920.

26. Ibid., 28 August 1920.

27. Ibid., 26 March 1921.

28. Tyne and Wear Archive Service [TWAS], T148/5, "Report of the Superintendent at Felling to Chief Constable of Durham", 21 May 1921.

29. TWAS, T148/6, "Report of the Superintendent at Felling to the Chief Constable of Durham", 20 March 1922.

30. See text of Bolton speeches from public platforms in May 1920 and December 1922, for example, in Blaydon Courier, 8 May 1920; 20 December 1922.

31. Blaydon Courier, 10 May 1924.

32. Ibid., 21 June 1924.

33. TWAS, T148/7, "Report of the Superintendent at Felling to the Chief Constable of Durham", 6 April 1924.

34. TWAS, T148/6, "Report of the Superintendent at Felling to the Chief Constable of Durham", 21 April 1922.

35. Barron, H., The 1926 Miners' Lockout. Meanings of Community in the Durham Coalfield (Oxford: Oxford University Press, 2009), p.151.

36. TWAS, T148/7, "Report of the Superintendent at Felling to the Chief Constable of Durham", 11 January 1925.

37. Blaydon Courier, 20 June 1925.

38. “Fight Like Hell” No.27, supplement Worker's Weekly, 10 December 1926; Blaydon Courier, 20 June 1925; L. Turnbull, Chopwell's Story, n.p.n.

39. Evening Chronicle, 1 April 1925.

40. Blaydon Courier, 10 October 1925. 
41. Ibid., 20 June 1925; Turnbull, Chopwell's Story, n.p.n.

42. Blaydon Courier, 15 December 1925.

43. Ibid., 24 April 1926.

44. Ibid., 18 May 1926; 8 June 81926.

45. [no named author], "A Council of Action - 40 Years Ago", Labour Monthly, Vol.48 (June, 1966), pp.269-271.

46. R. Page Arnot et.al., "The General Strike, 1926”, Our History, Issue 22 (1961), p.27.

47. Turnbull, Chopwell's Story, n.p.n.

48. R. Page Arnot et.al., "General Strike”, p.24; Turnbull, Chopwell's Story, n.p.n.

49. See Short, G., "The General Strike and Class Struggles in the North-East: 1925-28”, Marxism Today, 14 (October, 1970), pp.306-315.

50. Newcastle Journal, 14 May 1926.

51. Lawther quoted in M. Morris, The General Strike (Penguin, 1976), p.57.

52. Northern Light, No.3, n.d.; Workers' Chronicle, No.4, 7 May 1926 (General Strike Pamphlets, Gateshead Public Library).

53. Blaydon Courier, 22 May 1926.

54. Newcastle Journal, 14 May 1926.

55. Blaydon Courier, 22 May 1926; Turnbull, Chopwell's Story, n.p.n.

56. Ibid., 22 May 1926.

57. A. Mason, "The Miners" unions of Northumberland and Durham, with special reference to the General Strike of 1926" (Ph.D. thesis, Hull University, 1967), p.227.

58. A. Page et.al., "General Strike", p.27.

59. Parliamentary Debates, Vol.195, c.802, 13 May 1926.

60. A. Page et.al., "General Strike”, p.20.

61. See L. H. Mates, "Durham and South Wales Miners and the Spanish Civil War", Twentieth Century British History, 17:3 (2006), pp.383-385.

62. Blaydon Courier, 22 May 1926.

63. Newcastle Journal, 21 May 1926.

64. S. MacIntyre, "Red Strongholds Between the Wars", Marxism Today (March, 1979), p.85.

65. Ibid.,

66. Durham Chronicle, 9 October 1926; Turnbull, Chopwell's Story, n.p.n.

67. M. Morris, General Strike, p.103.

68. Blaydon Courier, 13 March 1953; Mates, Great Labour Unrest, pp.67-68.

69. Worker's Life, 27 May 1927.

70. See Blaydon Courier, 24 April 1926.

71. “The Miners” Voice”, No.33, supplement in Worker's Life, 9 September 1927.

72. Friends of Soviet Russia International Congress, November 1927. Report and Resolutions. (London: Labour Research Department, 1928); Blaydon Courier, 13 March 1953; Short, "General Strike", p.314.

73. Workers" Life, 27 July 1928.

74. North Mail, 16 February 1929.

75. Ibid.,

76. "Fight Like Hell" No.7, supplement Worker's Weekly, 23 July 1926; MacIntyre, "Red Strongholds", p.86.

77. L. H. Mates, The Spanish Civil War and the British Left: Political Activism and the Popular Front (I.B. Tauris, 2007), pp.23-24.

78. Northern Echo, 23 July 1934. See also L. H. Mates, “A 'Most Fruitful Period'? The North East District Communist Party and the Popular Front Period, 1935-9”, North-East History, 36 (2004), pp.54-98.

79. L. H. Mates, Spanish Civil War, pp.22-23. 
80. Daily Worker, 3 August 1936.

81. Evening Chronicle, 4 August 1936.

82. North Mail, 9 October 1936.

83. Ibid., 6 February 1937.

84. Ibid., 10 October 1936. See also critical letters in North Mail, 6 August 1936; 2 September 1936.

85. L. H. Mates, "Radical Cultures and Local Identities: the North-east Labour Movement's Response to the Spanish Civil War", in K. Cowman and I. Packer (eds), Radical Cultures and Local Identities (Newcastle: Cambridge Scholars, 2010), pp.213-231.

86. Durham Record Office, D/Sho 97, Blaydon CLP AR, 1936.

87. North Mail, 31 August 1936; Blaydon Courier, 29 August 1936.

88. North Mail, 19 August 1936.

89. See D. Watson, No Justice without a Struggle (Merlin Press, 2014).

90. Northern Echo, 23 July 1934; Blaydon Courier, 27 February 1937; 20 March 1937.

91. Blaydon Courier, 22 August 1936.

92. Ibid., 17 October 1936; Newcastle Journal, 17 November 1936.

93. Blaydon Courier, 20 March 1937. See Mates, "Durham and South Wales miners" and Spanish Civil War, pp.29-60.

94. Blaydon Courier, 2 January 1937.

95. Durham Chronicle, 19 March 1937.

96. See L. H. Mates, “The North-East and the Campaigns for a Popular Front, 1938-9", Northern History, 43:2 (2006), pp.273-301.

97. Blaydon Courier, 6 May 1938.

98. Ibid., 13 May 1938.

99. Ibid., 3 June 1938.

100. L. H. Mates, “Campaigns for a Popular Front”.

101. North Mail, 6 February 1939.

102. Tribune, 17 February 1939.

103. L. H. Mates, "Britain's De Facto Popular Front? The Case of the Tyneside Foodship Campaign, 1938-1939”, Labour History Review, 69:1 (2004), pp.323-345.

104. Newcastle Journal, 23 March 1955.

105. Blaydon Courier, 10 April 1942.

106. TWAS, Acc.5143, “An Appeal to the Miners of Durham” (n.d., February/March 1940)

107. Consett Chronicle, 2 April 1942.

108. Ibid.,

109. Ibid.,

110. Mates, "Most fruitful period?"

111. Mates, Great Labour Unrest, pp.107, 126.

112. Blaydon Courier, 10 April 1942.

113. Consett Chronicle, 2 April 1942.

114. The Times, 20 July 1942; Lawther, W., “Anglo-Soviet Trade Union Unity” Labour Monthly, 24 (March, 1942) pp.80-82; Sunday Sun, 9 April 1944.

115. Blaydon Courier, 13 March 1953.

116. Ibid., 10 May 1924.

117. L. H. Mates, Great Labour Unrest, p.22 and passim.

118. T. Benn, "The moral basis for democratic socialism", in C. Mullin (ed.), Arguments for democracy (Harmondsworth: Penguin), p.130.

119. R. Crossman, (ed.), The God That Failed. Six Studies of Communism (Hamish Hamilton, 1950). 


\section{ABSTRACTS}

Drawing inspiration from Kevin Morgan's recent study of trade unionist A.A. Purcell, this article analyses the activist commitment of Durham miner Henry Bolton; his changing ideology, and how this informed his political interventions in numerous contexts and through multifarious institutions and positions. Beginning his political journey as a Methodist and Liberal before converting to socialism, Bolton was particularly significant as a key example of a neglected but undoubtedly significant phenomenon; an influential left Labour Party activist whose politics were largely indistinguishable from that of Communists but who was only actually a party member (open or otherwise) for a very short period. Bolton's causes were numerous and interlinking. Working through the union, Labour Party and local council he advanced the interests of the miners and their communities, controversially harnessing the resources of the council itself during the 1926 general strike and lockout (he remained under long-term police surveillance). A firm believer in working-class education, Bolton was a leading figure in the regional Labour college movement and founder of a Socialist Sunday School branch. The latter formed the nucleus for local conscientious objectors during the Great War. In the 1930s, Bolton used his positions in both the council and region-wide peace council to propagandise on foreign affairs, including supporting the Spanish Republic. Studying Bolton's activist life throws considerable light on the complex and diverse political culture of the British left, richly demonstrating the vast number of different ways in which an activist could intervene in the political world, and the complexities of the ideologies on the Labour left.

Inspiré de l'étude récente par Kevin Morgan du syndicaliste A.A. Purcell, cet article vise à analyser l'engagement du mineur de la ville de Durham, Henry Bolton. Nous étudions son idéologie et les évolutions qui la caractérisèrent, ainsi que la manière dont ses idées donnaient forme à ses interventions politiques dans de nombreux contextes et au sein d'institutions diverses. Il commença son cheminement politique en tant que méthodiste et sympathisant du parti Liberal, avant de se convertir au socialisme. Son militantisme est marquant dans la mesure où il constitue un exemple d'un groupe peu étudié mais significatif: les militants de la gauche travailliste dont les positions politiques différaient très peu de celles du parti communiste; cependant, il fut membre du CPGB pendant très peu de temps. Bolton militait pour de nombreuses causes, liées les unes aux autres. A travers son activité syndicale , au sein du parti travailliste, et en tant que conseiller municipal, il défendait les intérêts des mineurs et de leur communauté: il prit une position controversée pendant la grève et le lockout de 1926, en mobilisant les ressources municipales pour la cause des mineurs (par la suite il fut longtemps surveillé par les forces de police). Bolton croyait profondément dans l'éducation ouvrière, et devint un dirigeant du mouvement des "Labour colleges" de la région, ainsi que le fondateur d'une "école socialiste du dimanche" (courantes à cette époque). Cette école devint le centre d'organisation local des objecteurs de conscience pendant la Grande Guerre. Dans les années 1930, Bolton utilisa sa position de conseiller municipal et militant du "Conseil Régional pour la Paix" pour tenter d'influencer la politique étrangère, et notamment pour soutenir la République espagnole. Cette étude de la vie militante de Bolton permet d'éclairer la culture politique complexe et diverse de la gauche britannique. 
INDEX

Mots-clés: communisme, syndicalisme, éducation ouvrière, méthodisme, mouvement ouvrier

Keywords: communism, Methodism, labour movement, working-class education, trade unions 